\title{
Peripheral neuropathy in acrodermatitis chronica atrophicans (Herxheimer)
}

\author{
H. C. HOPF \\ Neurological Department, University of Göttingen, Göttingen, W. Germany
}

SYNOPSIS Acrodermatitis chronica atrophicans is a dermatological condition that takes a chronically progressive course and finally leads to a widespread atrophy of the skin. Involvement of the is peripheral nervous system is frequently observed, predominantly a sensory polyneuropathy. General $\overrightarrow{0}$ reactions, the effect of penicillin treatment, the histological findings, and reports concerning a communicable agent transmittable from human to human as well in tissue cultures point to an infectious ${ }^{\omega}$ disease. Acrodermatitis chronica atrophicans follows a peculiar geographical distribution forming clusters of high prevalence in certain regions. Transmission by ticks is suggested.

The original description of acrodermatitis chronica atrophicans was that of Buchwald (1883), followed by Herxheimer and Hartmann (1902), and most descriptions of this clinical entity are to be found in the German-language literature. Essentially, it is a chronic disease (Oppenheim, 1931, Brünauer, 1935). Its characteristics are livid red skin changes initially showing signs of torpid inflammation, but finally, after a course of years, leading to dermal atrophy. It often begins unnoticed as complaints the significance of which is only later realized. The first dermatological changes consist of disseminated, bright red macular eruptions. They enlarge and gradually spread over adjacent regions, preferentially involving the extensor surfaces of the extremities and following their longitudinal axes. Finally they form net-like or striped designs, or more confluent lesions, progressively developing a livid red colour. Initially the areas involved appear oedematous and swollen, and have a soft, pasty consistency with fine scaling. At this stage histologically one finds an infiltration of plasma cells, round cells, mast cells, and histiocytes in the corium, with atrophy of the corium and epidermis following the inflammatory changes.

The skin surface feels soft and silky and can be

(Accepted 25 November 1974.) wrinkled into fine folds ('wrinkled cigarette $\stackrel{\text { जे }}{\mathrm{N}}$ paper'). Later, the entire cutis and subcutis are $ᄋ$ thinned, and veins, tendons, and other undeg- lying structures are recognizable. Histologically there is fragmentation and clumping of the elaste elements; the border between epithelium an cutis is flat and smooth; the papillae have dis or appeared. The Malpighian layer is clearly diminished and consists of a few layers of flattened acanthocytes, while the zona muscularis is largely destroyed. Sweat and sebum secretion is interrupted, the hair is thinned or missing, and $\triangle$ depigmentation appears. Hair follicles, sweat $\overrightarrow{\overrightarrow{0}}$ and sebaceous glands atrophy. In the deeper layers of the skin one finds changes in the blood vessels ranging from internal proliferation of arteries and veins to complete obliteration. Surface thickening consisting of relatively avascular connective tissue is encountered in $20 \%$ of cases, and knot-like connective tissue thickening - the so-called 'fibroid knots'-in about $10 \%$.

The usual location of chronic atrophic acro- $\bigcirc$ dermatitis is on the extensor surfaces of the extremities: on the arm over the elbows and along the ulna, and on the dorsa of the hands; on the legs over the patella and along the tibia, and the dorsa of the feet. The palmar surfaces of the hands and the soles of the feet are spared. According to Hauser (1958) predominant involvement of one extremity is the rule, so that, in one452 
quarter to one-third of cases of many years' duration, just one extremity is affected. In the remaining cases the changes ultimately develop on symmetrical regions of the opposite extremity, or on all four extremities. In a personal series of 26 patients from the Würzburg region skin changes were found on only one extremity in 18 cases with an average duration of illness of six years (Hopf, 1966). After an average duration of illness of $3 \frac{1}{2}$ years, patients from the Göttingen region had skin changes confined to one extremity in $34 \%$, both arms or legs in $38 \%$, and all extremities in $28 \%$ (Kaiser, 1972).

The onset of the illness is between the age of 20 and 40 years in most patients (Finger and Oppenheim, 1910; Jessner and Loewenstamm, 1924), with approximately $10 \%$ of cases beginning before the 20th year of age (Kafka, 1953). Most investigators have encountered a definite sexpredominance, women comprising $60-80 \%$ of the patient population (Hauser, 1958; Kaiser, 1972). Involvement of several members of the same family is occasionally observed (Hopf, 1966).

Accompanying lymph node enlargement (Hauser, 1958), elevation of ESR (in $70-90 \%$; Hauser, 1958), and elevation of serum gammaglobulin (in $60 \%$; Koskimies, 1953) suggest a generalized immune reaction. Since Nanna Svartz (1946) found that the cutaneous manifestations respond well to penicillin, acrodermatitis chronica atrophicans has been considered an inflammatory disease and Götz (1954) appears to have transmitted the disease from human to human.

Neurological disturbances were observed in patients with this disease quite early (Huber, 1900; Jessner, 1921 ; Jessner and Loewenstamm, 1924; Memmesheimer, 1931; and others). Initially, it was not clear whether manifestations such as paraesthesia, hyperaesthesia, and paresis were incidental to the dermatological disturbances or comprised a regular part of the syndrome. The first systematic investigation was that of Hopf (1966) and was continued in cooperation with Kaiser (1972) and Dress (1973).

\section{METHODS}

To date we have surveyed three different groups of patients. An initial group of 92 patients was investigated in the neurogical clinic of the University of
Würzburg under Professor G. Schaltenbrand and formed the basis for the first publication (Hopf, 1966). The second group consists of 109 patients from the Göttingen area. These 201 patients, identified primarily because of dermatological illness, were compared with a third group of 115 patients. This represents the largest such group in the literature, and was assembled for completion of the accompanying neurological symptoms.

\section{RESULTS}

COMPLAINTS The neurological symptoms presented by the three groups of patients are set out in Tables 1 and 2. Frequent complaints were pain, burning, hypersensitivity of the skin, feeling of furriness, numbness, 'crawling-ants' or tingling, sensations of heaviness, weakness, or

TABLE 1

COMPLAINTS OF PATIENTS SUFFERING FROM ACRODERMATITIS CHRONICA ATROPHICANS (HERXHEIMER)

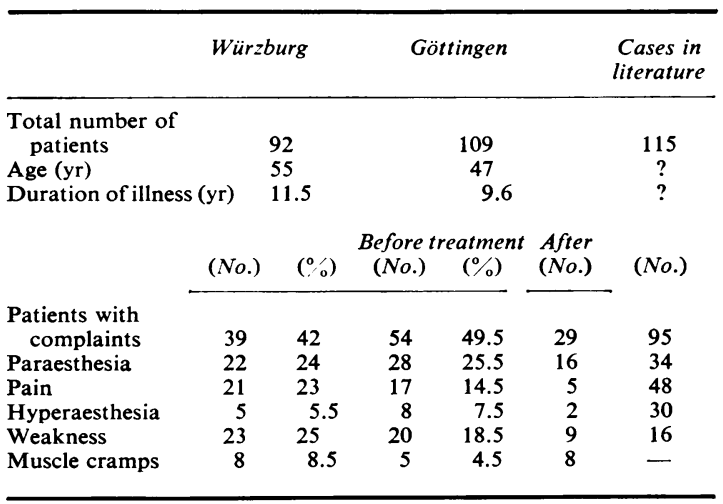

fatigue in the muscles, and, finally, muscle cramps. The frequency of appearance of these complaints is indicated in Table 1 . The complaints were usually most severe in the affected extremity, but their location did not always correlate with the skin areas that were affected, often appearing in the region of ostensibly normal skin. In general, $45 \%$ of the patients were symptomatic, and paraesthesias, pain, and feelings of 'weakness' were most prominent.

NEUROLOGICAL SIGNS Local disturbances of sensibility were particularly encountered in the 
TABLE 2

NEUROLOGICAL SIGNS OF PATIENTS SUFFERING FROM ACRODERMATITIS CHRONICA ATROPHICANS (HERXHEIMER)

\begin{tabular}{|c|c|c|c|c|c|}
\hline & \multicolumn{2}{|c|}{ Würzburg } & \multicolumn{2}{|c|}{ Göttingen } & \multirow{3}{*}{$\begin{array}{c}\text { Cases in } \\
\text { literature } \\
115 \\
? \\
? \\
(\text { No.) }\end{array}$} \\
\hline $\begin{array}{l}\text { Total number of patients } \\
\text { Age (yr) } \\
\text { Duration of illness (yr) }\end{array}$ & & $\begin{array}{l}2 \\
5 \\
1.5\end{array}$ & & 9.6 & \\
\hline & (No.) & $(\%)$ & (No.) & $(\%)$ & \\
\hline $\begin{array}{l}\text { Patients with neurological } \\
\text { signs } \\
\text { Hypaesthesia } \\
\text { Impaired vibration } \\
\text { Hyperpathia } \\
\text { Paresis } \\
\text { Muscle atrophy } \\
\text { Reflex disturbances }\end{array}$ & $\begin{array}{r}37 \\
26 \\
17 \\
4 \\
16 \\
6 \\
7\end{array}$ & \begin{tabular}{r}
\multicolumn{1}{c}{40} \\
28 \\
18.5 \\
4.5 \\
17.5 \\
6.5 \\
7.5
\end{tabular} & $\begin{array}{r}44 \\
19 \\
23 \\
6 \\
1 \\
3 \\
7\end{array}$ & $\begin{array}{c}40.5 \\
17.5 \\
21 \\
5.5 \\
1 \\
3 \\
6.5\end{array}$ & $\begin{array}{r}38 \\
25 \\
- \\
8 \\
13 \\
4\end{array}$ \\
\hline $\begin{array}{l}\text { Distribution of sensory } \\
\text { deficits } \\
\text { 'Local' type } \\
\text { 'Polyneuropathy' type }\end{array}$ & $\begin{array}{r}5 \\
23\end{array}$ & 25 & $\begin{array}{r}8 \\
15\end{array}$ & $\begin{array}{l}7.5 \\
14\end{array}$ & $?$ \\
\hline
\end{tabular}

early stages of the illness as hypaesthesia or hypalgesia, being observed in approximately $50 \%$ of our cases. A local reduction of sensation manifested itself as patchily-distributed hypaesthesia in atrophic skin areas. However, disturbance of sensibility was, in itself, not an obligatory feature in even the most atrophic end-stage.

About $40 \%$ of all patients had demonstrable neurological deficits, hypaesthesia and diminution of vibratory sense being most common (Table 2). These deficits mainly comprised a polyneuropathy which was usually, but not always, asymmetrical (Fig. 1). Therefore, more than half of the patients ( 25 of 40 ) with neurological deficits could be classified as having a polyneuropathy, and because of the asymmetrical distribution patterns the relationship to the spread of the dermatological lesion was unmistakable. While disturbances of sensibility

TABLE 3

CONDUCTION VELOCITY STUDIES IN 22 PATIENTS WITH ACRODERMATITIS CHRONICA ATROPHICANS

\begin{tabular}{|c|c|c|c|c|c|c|c|c|c|}
\hline $\begin{array}{l}\text { Patients } \\
\text { (no.) }\end{array}$ & $\begin{array}{c}\text { Age } \\
(y r)\end{array}$ & $\begin{array}{r}\text { Temp. } \\
\left({ }^{\circ} \mathrm{C}\right)\end{array}$ & Nerve & $\begin{array}{l}\text { S.c.v. } \\
(\mathrm{m} / \mathrm{s})\end{array}$ & $\underset{(\mathrm{m} / \mathrm{s})}{\text { M.c.v. }}$ & $\begin{array}{l}\text { Range } \\
(\mathrm{m} / \mathrm{s})\end{array}$ & $\begin{array}{c}\text { Term. } \\
\text { lat. } \\
(\mathrm{ms})\end{array}$ & $\begin{array}{l}\text { Pot. } \\
\text { dur. } \\
\text { (ms) }\end{array}$ & 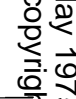 \\
\hline 1 & 62 & 34 & Ulnar & 59 & 56 & 15 & 2.5 & 12 & \\
\hline 2 & 57 & 33.8 & Ulnar & (7) & 52 & 21 & 3.1 & 17 & \\
\hline 3 & 66 & & Musculocut. & & 67 & & & $30^{*}$ & \\
\hline 4 & 51 & 33.0 & Ulnar & 54 & 55 & 14 & 2.9 & 15 & ఏ \\
\hline 5 & 63 & 34.2 & Ulnar & 47 & 50 & 18 & 4.5 & 17 & \\
\hline 6 & 55 & 33.8 & Ulnar & 59 & 56 & 15 & 2.5 & 14 & \\
\hline 7 & 58 & 33.8 & Ulnar & 54 & 67 & 25 & 3.9 & 18 & \\
\hline \multirow[t]{2}{*}{8} & 75 & 33.9 & Ulnar & & 62 & 24 & 2.3 & 14 & $\stackrel{10}{2}$ \\
\hline & & & Peroneal prox. & & 58 & & & & \\
\hline \multirow[t]{3}{*}{9} & 53 & $\begin{array}{l}32.1 \\
33.6\end{array}$ & Ulnar distal & 38 & $\begin{array}{l}35 \\
58\end{array}$ & 18 & 3.2 & 14 & 9 \\
\hline & J & & Peroneal prox. & & 36 & & & & \\
\hline & & 34.0 & distal & 42 & 35 & & & & \\
\hline \multirow{3}{*}{$\begin{array}{l}11 \\
12\end{array}$} & 39 & 33.7 & Ulnar right & 41 & $\begin{array}{l}55 \\
55\end{array}$ & 27 & $\begin{array}{l}4.9 \\
4.6\end{array}$ & $\begin{array}{l}19 \\
24\end{array}$ & \\
\hline & 47 & & Peroneal prox. & & 50 & & & & \\
\hline & & 33.9 & distal & + & 32 & & & & \\
\hline 13 & 69 & 34.4 & Ulnar & 41 & 51 & 19 & 2.9 & 16 & \\
\hline 14 & 64 & 34.0 & Ulnar & 49 & 62 & 17 & 2.8 & 13 & \\
\hline 15 & 50 & 33.3 & Ulnar & & 53 & 20 & 3.1 & 17 & \\
\hline \multirow[t]{2}{*}{16} & 60 & 33.6 & Ulnar & & 48 & 17 & 3.8 & 18 & \\
\hline & & 34.3 & Median & 42 & 55 & 25 & 7.1 & 15 & \\
\hline \multirow[t]{2}{*}{17} & 52 & & Peroneal prox. & & 37 & & & & \\
\hline & & 32.9 & distal & + & 21 & & & & \\
\hline \multirow{2}{*}{$\begin{array}{l}18 \\
19\end{array}$} & 53 & & Peroneal & + & 22 & & & & \\
\hline & 57 & 33.0 & $\begin{array}{l}\text { Peroneal prox. } \\
\text { distal }\end{array}$ & + & 46 & & & & \\
\hline \multirow{4}{*}{$\begin{array}{l}20 \\
21 \\
22\end{array}$} & 50 & 32.5 & Ulnar & 61 & 60 & 23 & 3.2 & 12 & \\
\hline & 57 & & Peroneal prox. & & 41 & & & $20^{*}$ & \\
\hline & & & Peroneal prox. & & 45 & & & & \\
\hline & & 34.1 & distal & 31 & 20 & & & & \\
\hline
\end{tabular}

Temp. = tissue temperature. S.c.v. = maximum sensory conduction velocity, digit to wrist. M.c.v. = maximum motor conduction velocity. Range= difference of conduction velocity between fast and slow fibres of the same nerve. Term. lat. = terminal latency. Pot. dur. = potential duration. * Repetitive afterdischarges. + No sensory potential. 

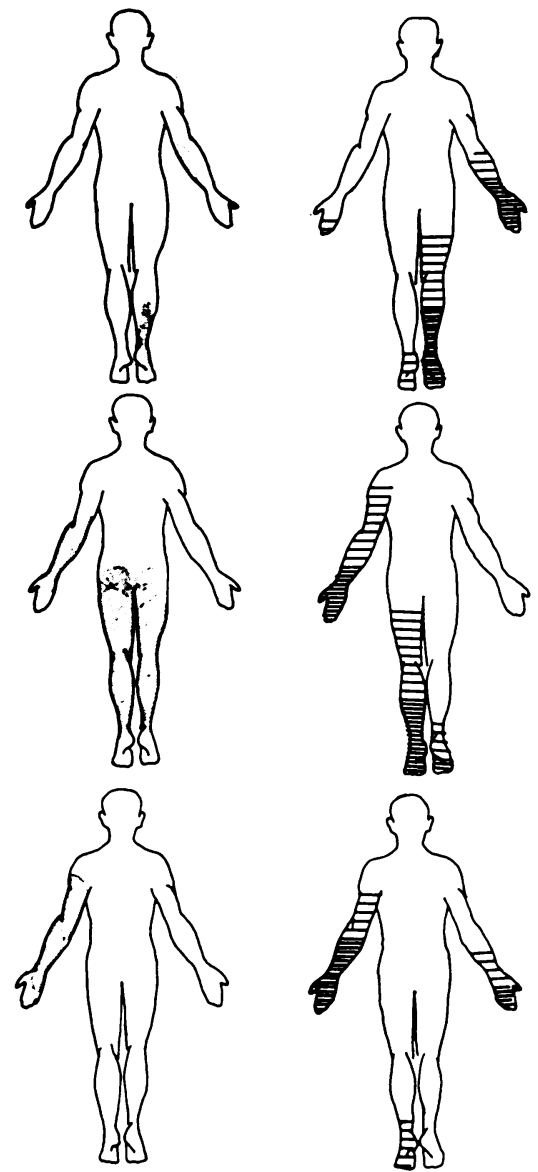

FIG. 1 Sensory disturbances (right) following the asymmetrical neuropathy type in three patients suffering from acrodermatitis chronica atrophicans, demonstrating a close correlation with the skin lesions (left) (from Hopf, 1966).

were found in the dermatologically healthyappearing extremities, they could, nevertheless, be demonstrated to be most severe and widespread in the extremities with the most advanced skin changes.

Often several symptoms or several neurological deficits coexisted in the same patient. However, patients with symptoms did not necessarily have neurological deficits, in the same way as there were patients with deficits but without complaints.

Electromyography confirmed that a polyneuropathy was the most common abnormality
(Table 3). Of eight patients in whom the maximum motor conduction velocity of the common peroneal nerve was measured, a slowing in the distal segment between the popliteal fossa and the head of the fibula was found in six. The distal motor latency was significantly prolonged in four of 16 patients. The evoked muscular action potential duration was increased in four and was in the upper range of normal in another four. The difference between fast and slow conducting motor fibres within one single nerve was increased in 12 cases. Conduction velocity of sensory fibres was decreased in 13 out of 18 patients.

Response to treatment Penicillin, 4 mega units per day over a two weeks period, ameliorated the eruption and the symptoms were definitely improved (Table 1). However, the neurological manifestations as well as the disturbances of sensibility in some patients were scarcely influenced, or progressed despite therapy. Admittedly, this reflects a relatively small number of cases.

EPIDEMIOLOGICAL ASPECTS When the cases in smaller areas are analysed, a striking distribution within certain regions is found. In the environs of Würzburg (Fig. 2) chronic atrophic acrodermatitis occurs far more often on the average in the rural districts of Tauberbischofsheim and Marktheidenfeld, as well as in an arbitrarilydefined district bounded by the Steigerwald. On the other hand, it is far less common in the rural districts of Bad Kissingen (Hopf and Stroux, 1968). For the Göttingen area the absolute frequency in comparison with the population, as well as the relative frequency in comparison with the total number of illnesses seen at the University Dermatology Clinic, have been determined. Accordingly, there was a significant frequency in the rural districts of Osterode and Witzenhausen, but a relative rarity in the Einbeck-AlfeldSalzgitter region (Fig. 3).

\section{DISCUSSION}

Acrodermatitis chronica atrophicans is not a rare condition on the continent. Nevertheless, the typical skin eruptions are often mistaken for simple trophic skin changes, scleroderma, or 


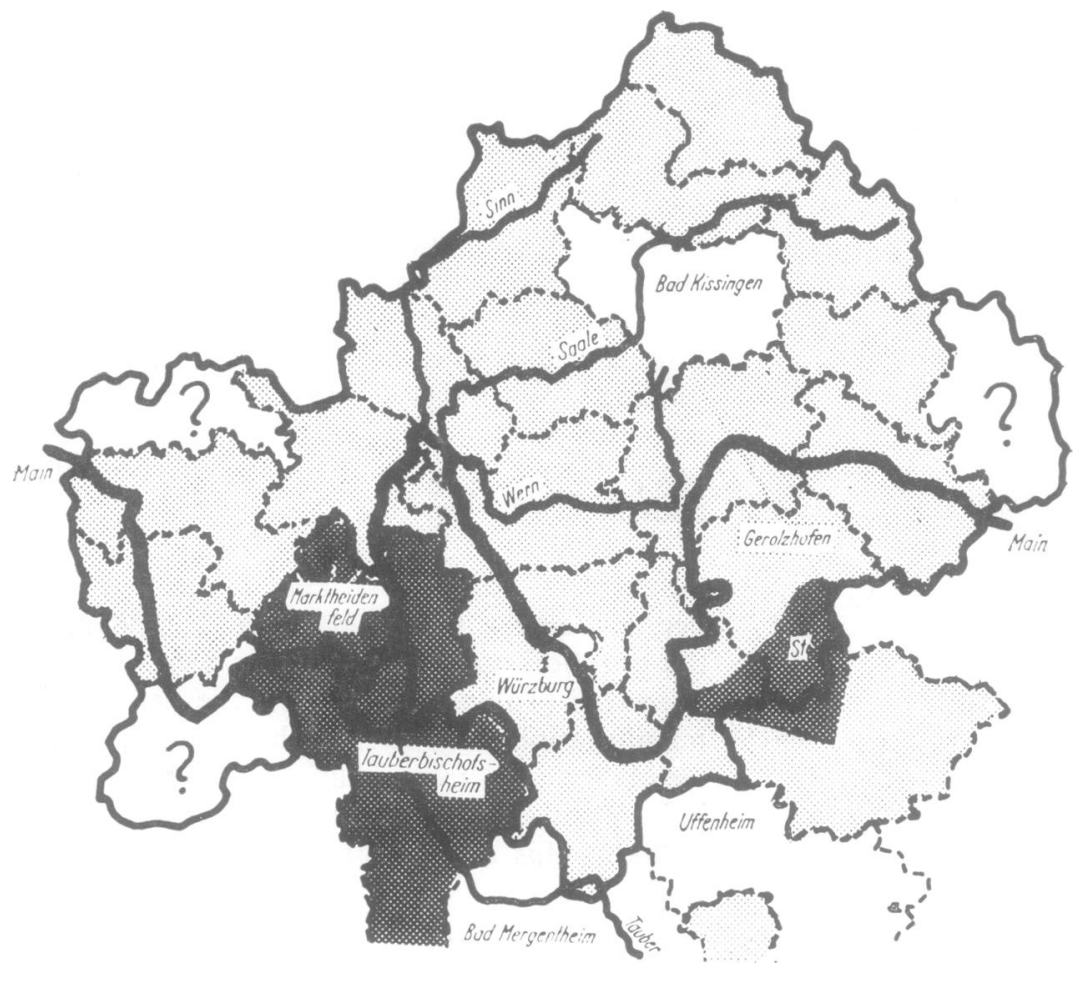

FIG. 2 Map of the rural districts of the Würzburg region. The prevalence of acrodermatitis chronica atrophicans is signifcantly higher than the average in the dark districts (Marktheidenfeld, Tauberbischofsheim, 'St') and significantly lower in the white districts (Bad Kissingen, Bad Mergentheim, Uffenheim). For the districts with question marks the prevalence was not calculated.

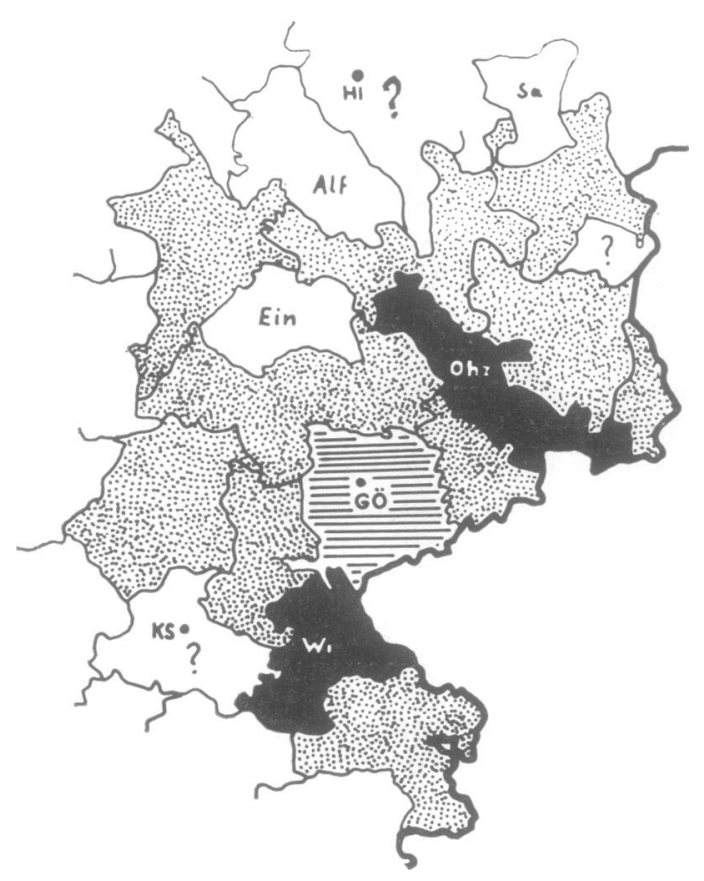

sequelae to involvement of the veins, to frostbite, or other influences. Thus, the physician should be familiar with the dermatological lesions.

Neurological symptoms have been observed in numerous cases. However, almost nothing was known about the frequency and nature of such findings. Many authors stated that, if anything, only local disturbances of cutaneous sensibility were to be expected in acrodermatitis chronica atrophica. Thus, several emphasized that the appropriate signs were absent in the affected skin regions (Buchwald, 1883; Pick, 1903; Zürn, 1913), while other stressed that paraesthesias

FIG. 3 Map of the rural districts of the Göttingen region. The prevalence of acrodermatitis chronica N atrophicans is significantly higher than the average in the dark districts (Osterode 'Oha', Witzenhausen $N$ (Wi') and significantly lower in the white districts ${ }_{\omega}^{N}$ Einbeck 'Ein', Alfeld 'Alf', Salzgitter 'Sa'). For the ত্ districts with question marks the prevalence was not 0 calculated. Göttingen ('Gö') was excluded. 
were also mentioned in uninvolved areas (Leven, 1903; Thyresson, 1949). Indeed, disturbances restricted to the affected skin areas do occur, but, more frequently, complaints and deficits correspond to the findings in peripheral neuropathy. Involvement of the peripheral nerves was confirmed in 17 of 22 patients investigated so far by evaluation of the conduction velocity of sensory and motor nerve fibres. The maximum sensory conduction velocity was below the 2 SD level in 13 patients (cases 5, 8-14, 16-19, 22 of Table 3 ), the distal latency was increased in four cases $(5$, $10,11,16)$, the maximum motor conduction velocity was decreased in six cases $(8,9,12,17$, $18,22)$, and the range of motor fibre velocities in one nerve was increased in 12 (cases $2,5,7-11$, $13-16,20)$ as compared with the values cited by Kaeser (1970), Hopf et al. (1974), and Hopf (1974) respectively.

As far as the effect of penicillin treatment is concerned nothing is known either about the infectious agent or the mode of action of antibiotics in this disease. Svartz (1946) just found empirically that penicillin is effective.

Several authors suggest that chronic atrophic acrodermatitis is transmitted by ticks. It has been observed, for example, that that disease may coexist and erythema chronicum migrans, as well as lymphadenosis benigna cutis (two dermatoses known to be transmitted by ticks) can coexist (Bäfverstedt, 1944; Hauser, 1958). It is in tickinfested areas that chronic atrophic acrodermatitis is frequent (Müller, 1966). Of particular interest in this respect is the report by Schaltenbrand and Müller (1973). From tissue from a patient with acrodermatitis they isolated a pathogen possessing high serological reactivity with serum from patients with communicable inflammatory diseases caused by ticks. These data support the hypothesis that acrodermatitis chronica atrophica is a tick-borne disease.

According to Danda (1963) Germany, Austria, and Czechoslovakia are the countries with the highest prevalence of chronic atrophic acrodermatitis. Cases in the French literature come almost exclusively from the Elsas (Hufschmitt, 1928; Weiss, 1936), while patients in AngloSaxon countries are usually immigrants. Our findings concerning its distribution in the environs of Würzburg and Göttingen demonstrated clustering of the disease in certain regions. It seems, therefore, that there are locationdependent factors that determine the appearance of chronic atrophic acrodermatitis. These factors are probably to be found in the tick population.

\section{REFERENCES}

Bäfverstedt, B. (1944). Über Lymphadenosis benigna cutis. Acta Dermato-Venerologica, 24, Suppl. 11.

Brünauer, S. R. (1935) Atrophien. In Die Haut- und Geschlechtskrankheiten, vol. 2, pp. 707-798. Edited by L. Arzt and K. Zieler. Urban and Schwarzenberg: Berlin. Buchwald, A. (1883). Ein Fall von diffuser idiopathischer Hautatrophie. Dermologische Vierteljahrsschrift, 10, 553556.

Danda, J. (1963). Die Weltfrequenz der Akrodermatitis chronica atrophicans. Hautarzt, 14, 337-340.

Dress, J. (1973). Die geographische Verteilung der Acrodermatitis chronica atrophicans (Herxheimer) in der Umgebung von Göttingen. M.S. Thesis: Göttingen.

Finger, E., and Oppenheim, M. (1910). Die Hautatrophien. Deuticke: Wien.

Götz, H. (1954). Die Acrodermatitis chronica atrophicans Herxheimer als Infektionskrankheit. Hautarzt, 5, 491-504.

Hauser, W. (1958). Atrophien. In: Dermatologie und Venerologie, vol. 2, part 2, pp. 883-885. Edited by H. A. Gottron and W. Schönfeld. Thieme: Stuttgart.

Herxheimer, K., and Hartmann, K. (1902). Über Acrodermatitis chronica atrophicans. Archiv für Dermatologie und Syphilis 61, 57-76, 255-300.

Hopf, H. C. (1966). Acrodermatitis chronica atrophicans (Herxheimer) und Nervensystem. Monographien aus den Gesamtgebiete der Neurologie und Psychiatrie, 114, 1-130.

Hopf, H. C. (1974). Impulsleitung im peripheren Nerven. In Elektromyographie. Edited by H. C. Hopf and A. Struppler. Thieme: Stuttgart.

Hopf, H. C., Le Quesne, P., and Willison, R. G. (1974). Refractory periods and lower limiting frequencies of sensory fibres of the hand. In Neuromuscular Diseases. Edited by H. Kunze and E. Desmedt. Karger: Basel.

Hopf, H. C., and Stroux, B. (1968). Die geographische Verteilung der Akrodermatitis chronica atrophicans (Herxheimer) in der Umgebung von Würzburg. Zeitschrift für Haut- und Geschlechtskrankheiten, 43, 41-48.

Huber (1900). Ueber Atrophia idiopathica diffusa progressiva cutis im Gegensatze zur senilen Atrophie der Haut. Archiv für Dermatologie, 52, 71-90.

Hufschmitt, G. (1928). Deux cas de dermatite chronique atrophiante. Bulletin de la Société Française de Dermatologie et de Syphiligraphie, 35, 95-96.

Jessner, M. (1921). Zur Kenntnis der Akrodermatitis chronica atrophicans. Archiv für Dermatologie und Syphilis, 134, 478-487.

Jessner, M., and Loewenstamm, A. (1924). Bericht über 66 Fälle der Akrodermatitis chronica atrophicans. Dermatologische Wochenschrift, 79, 1169-1170.

Kaeser, H. E. (1970). Nerve conduction velocity measurements. In Handbook of Clinical Neurology, vol. 7, pp. 116196. Edited by P. J. Vinken and G. W. Bruyn. NorthHolland: Amsterdam.

Kafka, J. (1953). Statische Erhebungen über die Fälle von Acrodermatitis chronica atrophicans (Herxheimer-Hartmann) an der Universitätshautklinik Gießen 1906-1952. M.S. Thesis: Gießen. 
Kaiser, M. (1972). Neurologische Komplikationen bei Acrodermatitis chronica atrophicans und ihre Beeinflussung durch die Penicillintherapie. M.S. Thesis: Göttingen.

Koskimies, A. (1953). Acrodermatitis atrophicans (Herxheimer). Eine klinische und serologische Studie über 57 Fälle. (Abstract.) Dermatologische Wochenschrift, 128, 922923.

Leven, L. (1903). Acrodermatitis chronica atrophicans (Herxheimer-Hartmann). Archiv für Dermatologie und Syphilis, 65, 247-254.

Memmesheimer, A. (1931). Hautatrophie Zentrablatt für Haut- und Geschlechtskrankheiten sowie deren Grenzgebiete, 38, 737.

Müller, W. (1966). Orientierende Untersuchung über die Zeckenaktivität in der Umgebung von Würzburg während der Vegetationsperiode des Jahres 1965. Deutsche Zeitschrift für Nervenheilkunde, 189, 259-275.

Oppenheim, M. (1931). 'Atrophien'. In: Handbuch der Haut- und Geschlechtskrankheiten, vol. 8, part 2, pp. 500-716. Edited by J. Jadassohn. Springer: Berlin.

Pick, W. (1903). Atrophica idiopathica cutis. Archiv für Dermatologie und Syphilis, 66, 161-162.

Schaltenbrand, G., and Müller, W. (1973). Tick virus diseases in Germany. Symposion on tick virus diseases, Giessen, 1973.

Svartz, N. (1946). Penicillinbehandlung vid dermatitis atrophicans Herxheimer. (Abstract.) Nordisk Medicine, 32, 2783.

Thyresson, N. (1949). Penicillin treatment of acrodermatitis chronica atrophicans (Herzheimer). Acta DermatoVenerologica, 29, 572-621.

Weis, J. (1936). Dermatite chronique atrophiante. Bulletin de la Société Française de Dermatologie et de Syphiligraphie, 43, 1391-1392.

Zürn (1913). Acrodermatitis chronica atrophicans. (Abstract.) Dermatologische Zeitschrift, 20, 334. 